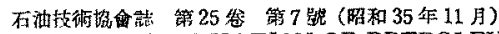

JOURNAL OF THE JAPANESE ASSOCIATION OF PETROLEUM TECHNOLOGISTS

VOL. 25, NO. 7 (Nov, 1960)

\title{
八橋油田の逸泥とその防止関する研究
}

\author{
松本仙 一*五十嵐正己*
}

(昭和 35 年 8 月 9 日受理)

\section{Study on the Lost Circulation in Yabase Oil Field}

By

Sen-ichi Matsumoto and Masomi Igarashi

\begin{abstract}
The lost circulation in Yabase oil field is discussed, and method for preventing the lost circulation is described in this paper.
\end{abstract}

\section{1. まえがき}

いわゆる冕泥（逸水）とは、ロ一タリ一式掘鳘に招い

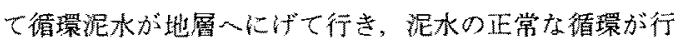
われないことである。したがつて地層中に泥水の入る空

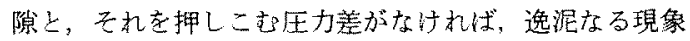
はおこらないわけである。

この泥水の入つてゆく部分として考えられるのは，洞

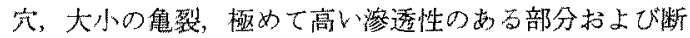
畨等があげられる。その条件によつて遀泥の規模は種々

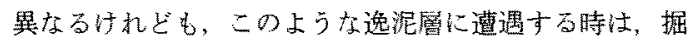
進が涉らないばかりか，経济的にも莫大な損失索安极く ことになる。

それで冕泥に刘する処置としては，

(1)地症に及ぼす圧力をでるだけ低くする。

(2) 冕泥層范充填末たは閶塞するために，泥水中に逸 泥防止都莸混合する。

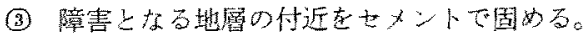

(4)盲掘りして掘愿を逻泥部分に運びこませる。 等の方法がしら札るわけであるが，逸泥瑟の克服という

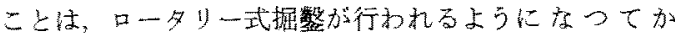
ら，重要度拔的間題となつている。

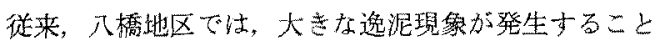

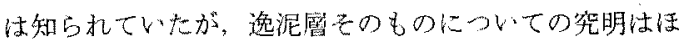

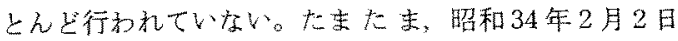
開坑された八橋 R. 149 号节拉よで昭和 34 年 12 月 14 日 仁開坑された八橋 R.150号井において，逸泥になやま

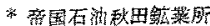

されたので，筆者等はこの八橋地区の過去に㧍ける逸泥 記録を整理して，その逸泥層と逻泥状況安明らかにし， さらにR. 150 号井にて逸泥層と推定されるところの砂 利が探取されたので，こ机老使用して，極的下漈透率の

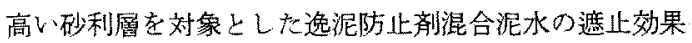
について調べた。以下これらの研究結果について報告す z。

\section{2. 八橋地区の概念}

八欈油田の逸泥は八橋地区が鼠も多く，雄物川地区の 一部をのぞき，他の地区には汪とんどみられない。した がつて調查は八橋地区に限定して行つた。八橋梂区恃南 北に走る八橋背斜の中心部であつて，高野地区と雄物川 地区にはさまれた部分である(第 1 図参照)。この地区は 昭和の初期より開発され，現在までに上総掘 30 纣，網 掘 99 坑，口ー夕り一掘 153 坑加凪られている。これら

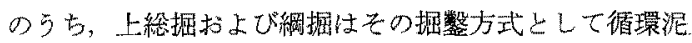
水が使用されないので，逸泥現缘老把握するのに困難で

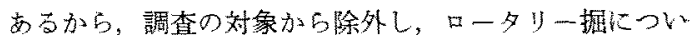
てのみ謂心゙た。しかしロタリ一掘でも初期のものは記

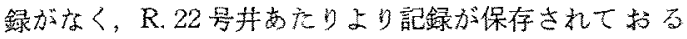
けれども，その後のむのの中にも若下抜けているとこる もあり，結局調查した坑井数快116坑であつた。この ち93坑は逸泥があり，23坑山全く逸泥がなかつた。 た晩泥した 93 坑の5ち58坑は一応晩泥が止如られたけ

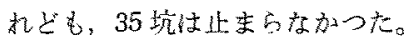

\section{3. 逸泥層の深度}

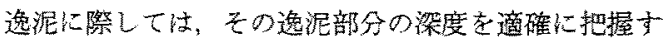




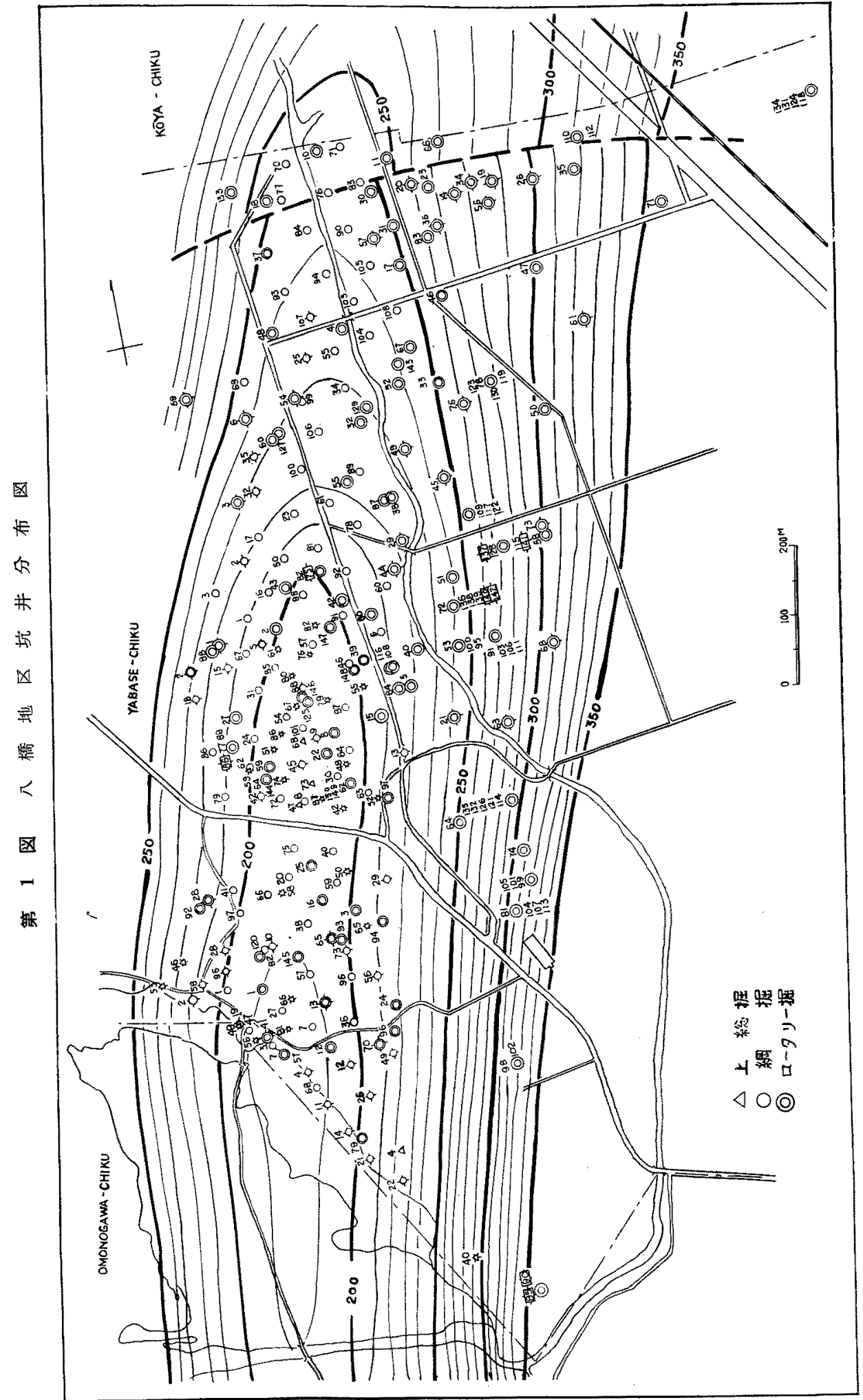


ることが最も重要なことであり、これが判明すれば，そ の処犆が重点的に障害のある綯所にのみ集中され，無䭾 がなくなるわけである。

八橋地区の逸泥は比較的広籍囲に亘つておる。したが つて洞穴・亀裂あるいは断層等の如きものではなく，連 続した地層で，非常に粗い，高い渗透率の層であること が容易に推定される。第 2 図は八橋亚層のコンターマッ プである。この八橋背斜軸の积断面図Xと，これと平行 な縦断面図Y招よびこれらに直角な横断面㘠 A, B C C D を描き,これら各線上り $50 \mathrm{~m}$ 以内にある各坑井の逸泥 深度を記入したものが，3第図拉よび第 4 図である。な お同一坑井に招いて，市る梁度で冕泥があつてこれが止 り，さらに掘進していつた時に再び逸泥があつたような 場合には，それが新しい逸泥層であるのか，あるいは上
部の一度止つた逸泥層が再び逸泥をはじめたのかは, 特 別な手段を用いて測定していなければ明確でないわけで あるが，一応井戸の記録通り記入してある。これらの図 をみると，若干の例外はあるけ扎ども，ほとんどが八橋 III層からIV層にかけての閒で逸泥していることが明らか である。

\section{4. 逸泥の状況}

次に晩泥の大きさはどの程度であるかといらことにつ いて述べるが，冕泥量の記録というものは，大体に抽い て大雑把であるし，また記録されていないものが多い。 特に盲掘（水掘）が行われたとさは，ほとんどその量的 な記録がない。しかし記録のあるものを整理してみる

第目

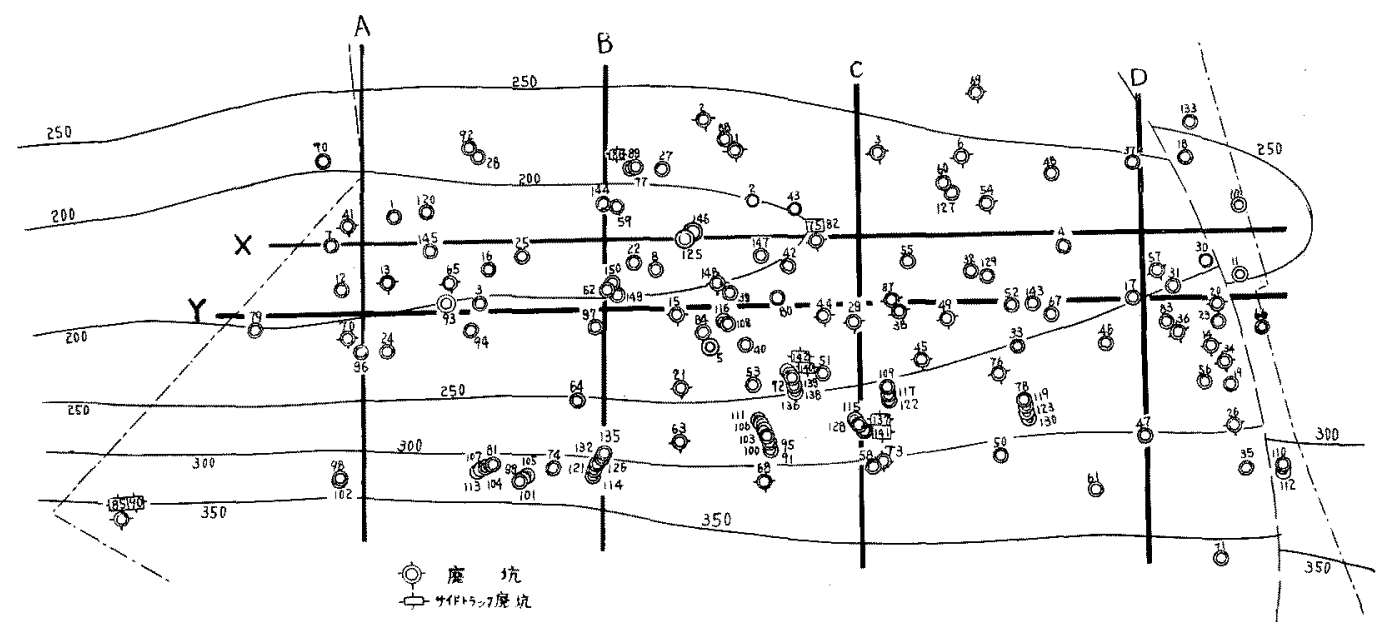

第 3 図-1 X線各坑并D逸泥深度

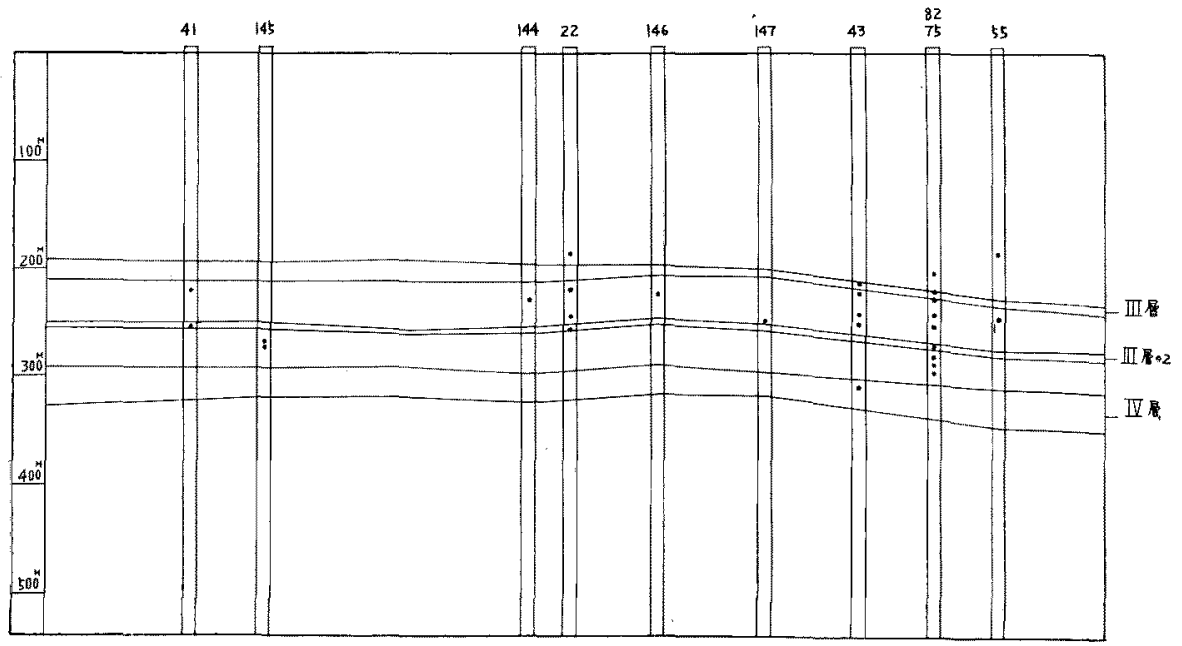


八橋油田の魀泥とその防止に関する研究

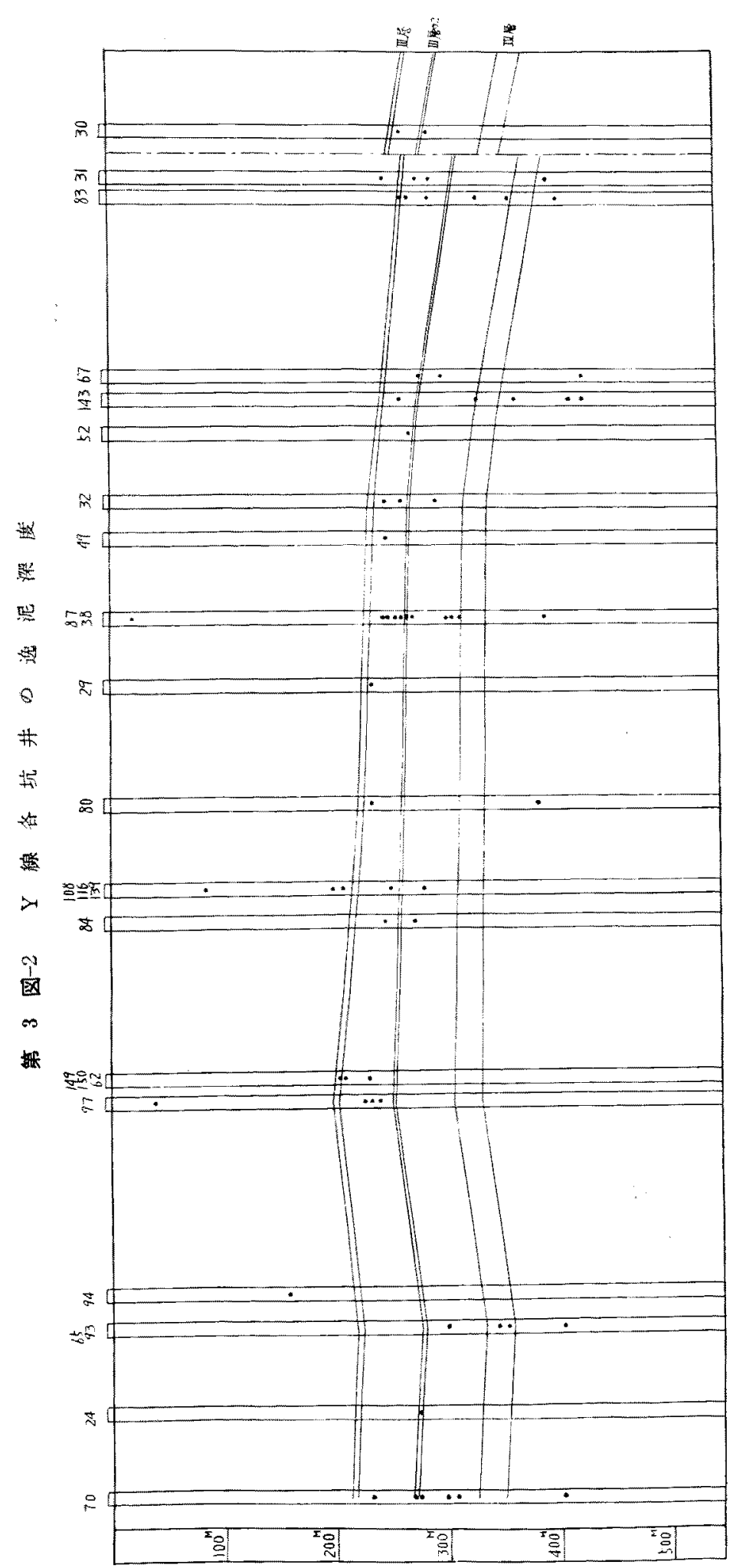



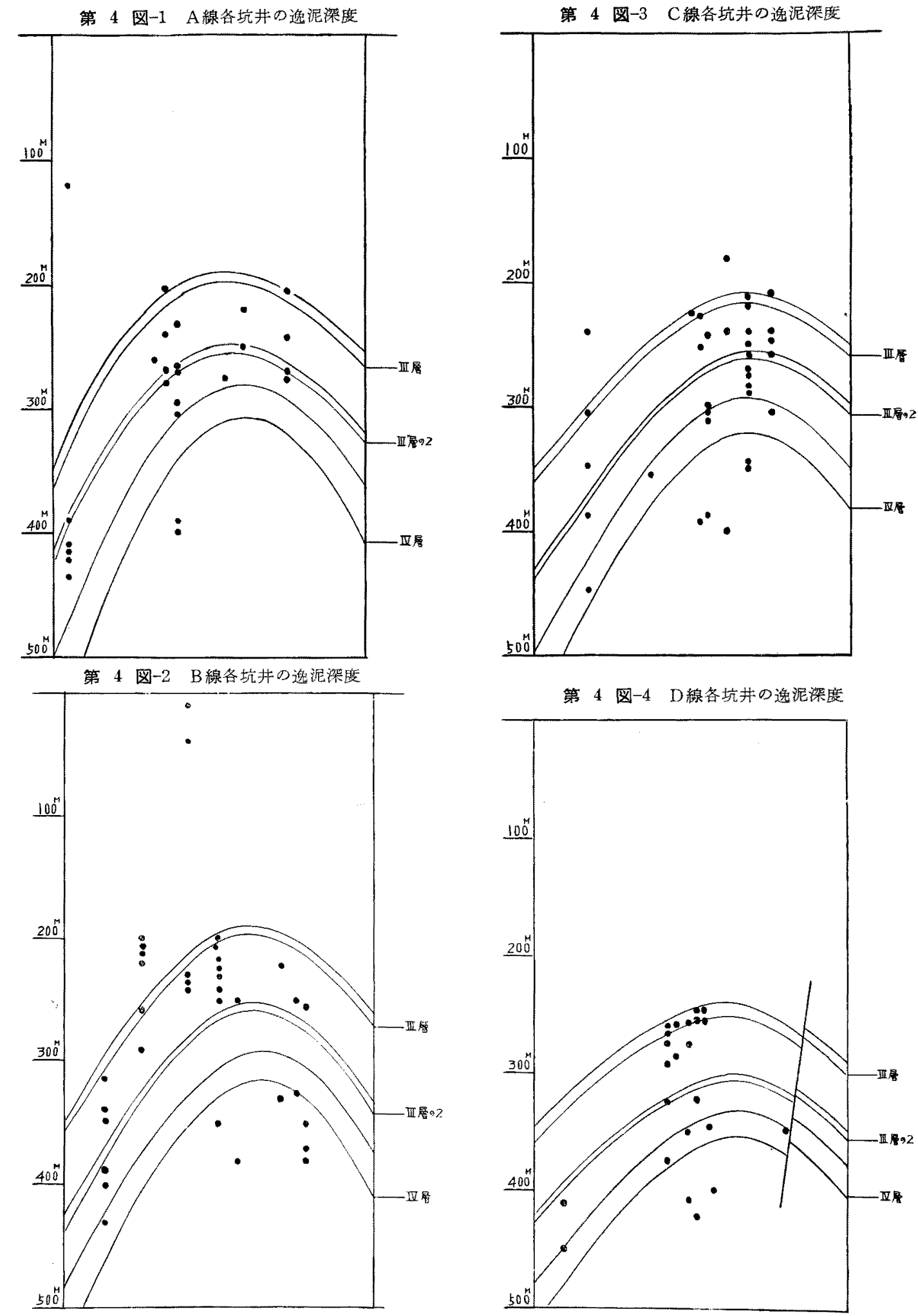

第 4 图-4 D線各境茾口魀泥楔度

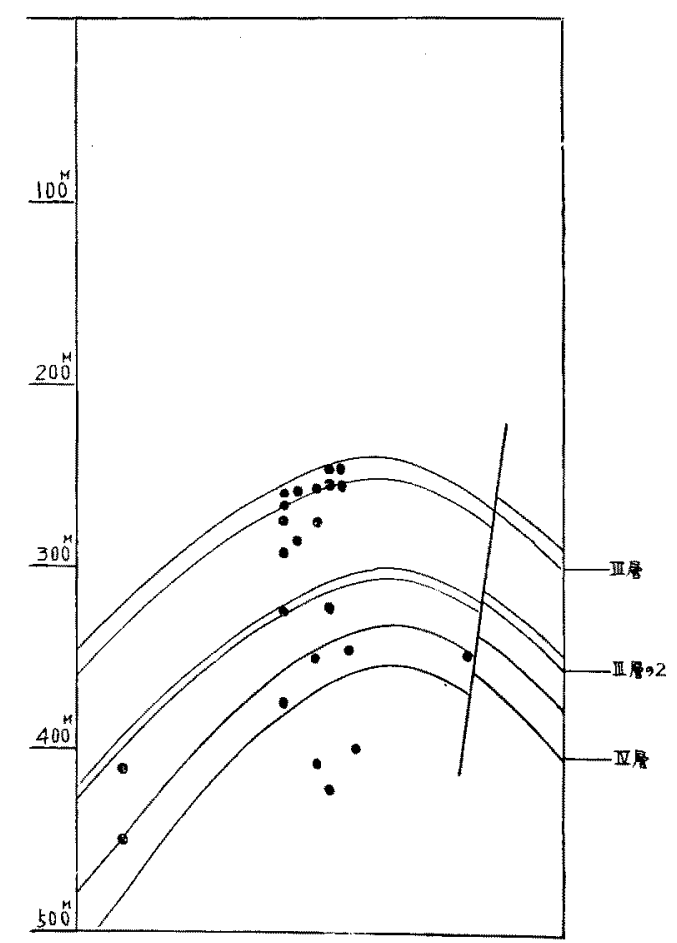




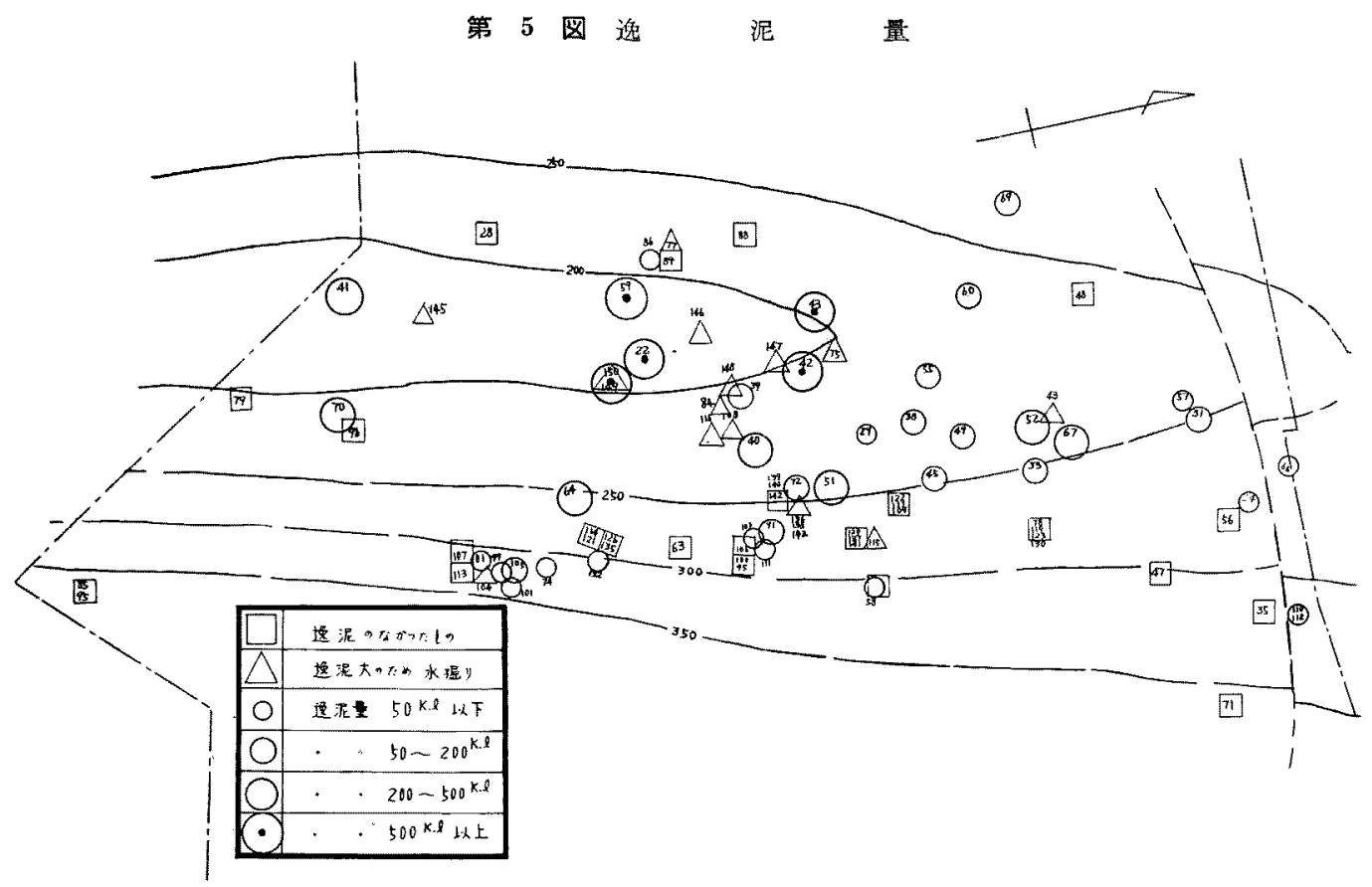

と，その傾向を充分つかむことができる。第 5 図はその 逸泥量を6ツに分類して図示したものである。これら逸 泥量のうち晩泥がはげしくて途中水掘に切替えられたも の注，円の中に三角を入れ，円の大きさで泥水と清水の 地層へにげた合計量を示し，水掘の行われた記録はある が量的な記録のないものは，単に三角のみで表わした。 水掘の行われたということは，逸泥量の大であうた証拠 であるから，量的な記録がなくても一応記入したわけで ある。なお，記号の中の数字は井戸番号である。この図 上り，背斜の軸に沿 $5 ，$ R. $22 ，$ R. $42 ，$ R. 43 ， R. 59 , R. 149 およびR. 150 号井等の含まれる部分が最も逸泥 のはげし、ことがわかる。また R. 22 号井は八橋地区の 中心部にあり，比較的古い井戸であるけれども， $500 \mathrm{kl}$ 以上の逸泥が記録されて招り，かなり初期の頃から逸泥 のあつたことがわかる。しかし同一地層で接近した坑井 であつても，量的に差異の大きなものがある。これは恐 らく，1 次的南るいは 2 次的な原因に上る粗密に基すく ものであると思われる。

\section{5. 過去における逸泥防止剂の使用}

前に述バたように逸泥層に対する処置として，地層に からる压力をなる心゙く少なくするとか，積極的に逸泥部 分を充填閉塞するとか，あるいは盲掘によつて掘屑を充 填しながら掘進してゆくとか，種々方法はあるけれど も，珹機的な対策は一応これ省き，いわ的逸泥防止
剤を中心とした逸泥対策について，範围を八橋地区に限 定し，過去の記録をまと第6 図に示す。初期の頃には 主としてセメントおよびベントナイトが使用され，その 後和ら・ファイバー・テック等のフォイバー状物翼, マ イカ・セロファン等のフレイタ状物質, パーライト・扔 が屑・タフプラグ等の粒状物質が単独にあるいは 2,3 種類同時に, 泥水中あるいはセメントミルク中に混合さ れて，障害箇所に送られている。また地層にか〉る泥柱 压をなるべく少なくなるたかに，泥水中に泡を混合して その比重を軽くしてやる目的で，ネオペレックスが 29 年より使わ机ているが，こ机は予防的にも盛んに用いら れている。

しかしながら，八梧地区のような逸泥層では，単に泥 柱圧を少く寸るのみではこれを防ぐことはできない。第 1 表に晩泥の最も大きい部分の 2 坑井，すなわち R. 149 号井とR. 150 号井で掘進中, 最初の逸泥が発生した樑 度と泥水比重, ならびにその時の水頭を示す。

\begin{tabular}{|c|c|c|c|}
\hline 坑井名 & 泥水比重 & 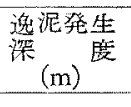 & 水 ${ }_{(\mathrm{m})}$ 頭 \\
\hline R. 149 & 1.02 & 228.9 & 45 \\
\hline R. 150 & 0.98 & 297.5 & 54 \\
\hline
\end{tabular}

なお掘整諸装置切よび据籢技術は年を追つて淮歩して 来ているし，また逸泥防止方法および作業方針も各時代 
第 6 図過去に招いて使用された冕泥防止材料

\begin{tabular}{|c|c|c|c|c|c|c|c|c|c|c|c|c|c|}
\hline \multirow{2}{*}{ 昭和 年 } & \multirow{2}{*}{ 烄前名 } & \multirow{2}{*}{ 深度 } & \multirow{2}{*}{ 自 } & \multirow{2}{*}{ 〜 至 } & \multirow{2}{*}{ 逸泥䏝部 } & \multirow{2}{*}{ 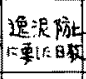 } & \multicolumn{6}{|c|}{ 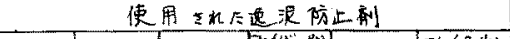 } & \multirow[b]{2}{*}{ 其的地 } \\
\hline & & & & & & & $5 x+1$ & 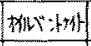 & 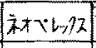 & 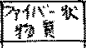 & 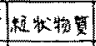 & \begin{tabular}{|l|l|}
71,12 \\
$x^{2}$
\end{tabular} & \\
\hline 14 & 22 & 836.4 & 12.8 & ${ }^{15} 11.10$ & 0 & 74 & & & & & & & \\
\hline 15 & $\begin{array}{l}24 \\
27 \\
28 \\
29 \\
30 \\
31 \\
32 \\
34 \\
\end{array}$ & $\begin{array}{l}894 \\
457.5 \\
1004.5 \\
450 \\
450.4 \\
850 \\
382.8 \\
448.5 \\
\end{array}$ & $\begin{array}{l}4.2 \\
1.29 \\
3.28 \\
7.22 \\
5.22 \\
8.8 \\
10.21 \\
11.29\end{array}$ & $\begin{array}{r}1.26 \\
3.24 \\
8.11 \\
7.16 \\
7.12 \\
161.29 \\
12.17 \\
162.9\end{array}$ & & $\begin{array}{c}1 \\
2 \\
- \\
4 \\
4 \\
10 \\
11 \\
14\end{array}$ & & & & & & & 石瓜惯湿 \\
\hline 16 & $\begin{array}{l}26 \\
33 \\
35 \\
36 \\
37 \\
38 \\
39\end{array}$ & $\begin{array}{c}1022,3 \\
500 \\
1100 \\
456 \\
413 \\
402.6 \\
949.2\end{array}$ & $\begin{array}{l}1.20 \\
3.19 \\
9.8 \\
7.27 \\
1.14 \\
6.8 \\
5.8 \\
\end{array}$ & $\begin{array}{c}4.29 \\
10.17 \\
11.27 \\
3.21 \\
11.7 \\
8.24\end{array}$ & & $\begin{array}{c}9 \\
30 \\
-3 \\
1 \\
11 \\
13 \\
\end{array}$ & (C) & & & & & & \\
\hline 17 & $\begin{array}{l}40 \\
41 \\
42 \\
43 \\
47 \\
\end{array}$ & \begin{tabular}{|c|}
451.7 \\
510 \\
1062.6 \\
503 \\
751 \\
\end{tabular} & $\begin{array}{r}3.10 \\
7.1 \\
5.18 \\
12.8 \\
9.23 \\
\end{array}$ & $\begin{array}{r}5.23 \\
9.18 \\
11.18 \\
18.13 \\
2.2 \\
\end{array}$ & & $\begin{array}{l}15 \\
20 \\
15 \\
42 \\
-\end{array}$ & (C) & & & & & & \\
\hline 18 & $\begin{array}{l}45 \\
46 \\
48 \\
48 \\
50 \\
51 \\
52 \\
53 \\
55 \\
56\end{array}$ & $\begin{array}{l}1121 \\
1150 \\
508.6 \\
530 \\
1160 \\
1100 \\
1100 \\
1042.3 \\
1100 \\
1100\end{array}$ & $\begin{array}{c}3.15 \\
5.6 \\
6.11 \\
11.12 \\
2.15 \\
1.23 \\
7.11 \\
12.16 \\
10.9 \\
9.2\end{array}$ & $\begin{array}{r}6.10 \\
7.17 \\
7.15 \\
19 \\
1.23 \\
5.27 \\
34.7 \\
49.3 \\
199.5 \\
11.1 \\
11.20 \\
\end{array}$ & & $\begin{array}{l}3 \\
8 \\
- \\
5 \\
2 \\
3 \\
3 \\
3 \\
4 \\
-\end{array}$ & & & & & & & 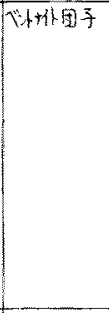 \\
\hline 19 & $\begin{array}{l}57 \\
58 \\
59 \\
60 \\
61 \\
62 \\
63 \\
64 \\
65 \\
66 \\
67\end{array}$ & $\begin{array}{c}1100 \\
1150 \\
500 \\
471 \\
1150 \\
795 \\
1090 \\
1100 \\
8052 \\
500 \\
470\end{array}$ & $\begin{array}{l}1.17 \\
4.12 \\
2.29 \\
7.26 \\
5.28 \\
5.15 \\
6.25 \\
8.3 \\
10.27 \\
5.27 \\
9.27 \\
\end{array}$ & $\begin{array}{cc}7 & 8.12 \\
2 & 6.10 \\
9 & 4.21 \\
6 & 9.27 \\
8 & 8.2 \\
5 & 9.9 \\
5 & 12.26 \\
3 & 10.6 \\
70 & 3.5 \\
7 & 7.20 \\
7 & 11.24 \\
\end{array}$ & & $\begin{array}{c}3 \\
2 \\
28 \\
10 \\
2 \\
50 \\
- \\
2 \\
70 \\
1 \\
8 \\
\end{array}$ & $\begin{array}{l}G C \\
G C \\
G C \\
G C\end{array}$ & & & & & & \\
\hline 20 & $\begin{array}{l}68 \\
80 \\
\end{array}$ & $\begin{array}{l}1200.1 \\
1072\end{array}$ & $\begin{array}{l}2.5 \\
5.17 \\
\end{array}$ & $\begin{array}{r}6.28 \\
22.29 \\
12.29 \\
\end{array}$ & & $\begin{array}{r}4 \\
40 \\
\end{array}$ & (c) & & & & & & \\
\hline 23 & 69 & 1046.4 & 2.16 & 6.18 & & 5 & & & & & & & \\
\hline 24 & 70 & 1402 & 6.16 & 25.24 & & 15 & (60) & & & $M$ & & (9) & \\
\hline 25 & 71 & 1783 & 8.29 & -265.31 & $\Delta$ & $=$ & & & & & & & \\
\hline 26 & 72 & 1390 & $122 ?$ & ${ }^{27} 7.8$ & & 6 & & & & & & & \\
\hline 27 & $\begin{array}{l}73 \\
74\end{array}$ & $\begin{array}{l}1798.4 \\
1819\end{array}$ & $\begin{array}{l}7.2 \\
2.28\end{array}$ & $\begin{array}{r}12.30 \\
\quad \quad 7.13 \\
\end{array}$ & & $\begin{array}{r}10 \\
9 \\
\end{array}$ & 60 & & & & & (9) & \\
\hline 28 & $\begin{array}{l}75 \\
77 \\
78 \\
79 \\
\end{array}$ & $\begin{array}{l}1682 \\
1720 \\
2031.2 \\
256.2\end{array}$ & $\begin{array}{l}2.26 \\
5.8 \\
8.5 \\
8.28\end{array}$ & $\begin{array}{r}6.3 \\
9.7 \\
29.17 \\
2.17 \\
9.5\end{array}$ & & $\begin{array}{r}33 \\
24 \\
9 \\
-\end{array}$ & 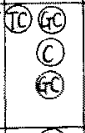 & & & $\frac{W}{W}$ & & (19) & \\
\hline 29 & $\begin{array}{l}81 \\
83 \\
84 \\
85 \\
86 \\
87\end{array}$ & $\begin{array}{l}1858.1 \\
1800 \\
265 \\
1750 \\
1569.8 \\
1520\end{array}$ & $\begin{array}{l}2.24 \\
6.12 \\
6.30 \\
7.15 \\
7.24 \\
8.31\end{array}$ & $\begin{array}{r}7.7 \\
10.11 \\
7.12 \\
9.23 \\
9.22\end{array}$ & & $\begin{array}{l}20 \\
11 \\
4 \\
11 \\
14\end{array}$ & $\begin{array}{l}\frac{90}{90} \\
60\end{array}$ & & 0 & F & & (M) & i \\
\hline
\end{tabular}




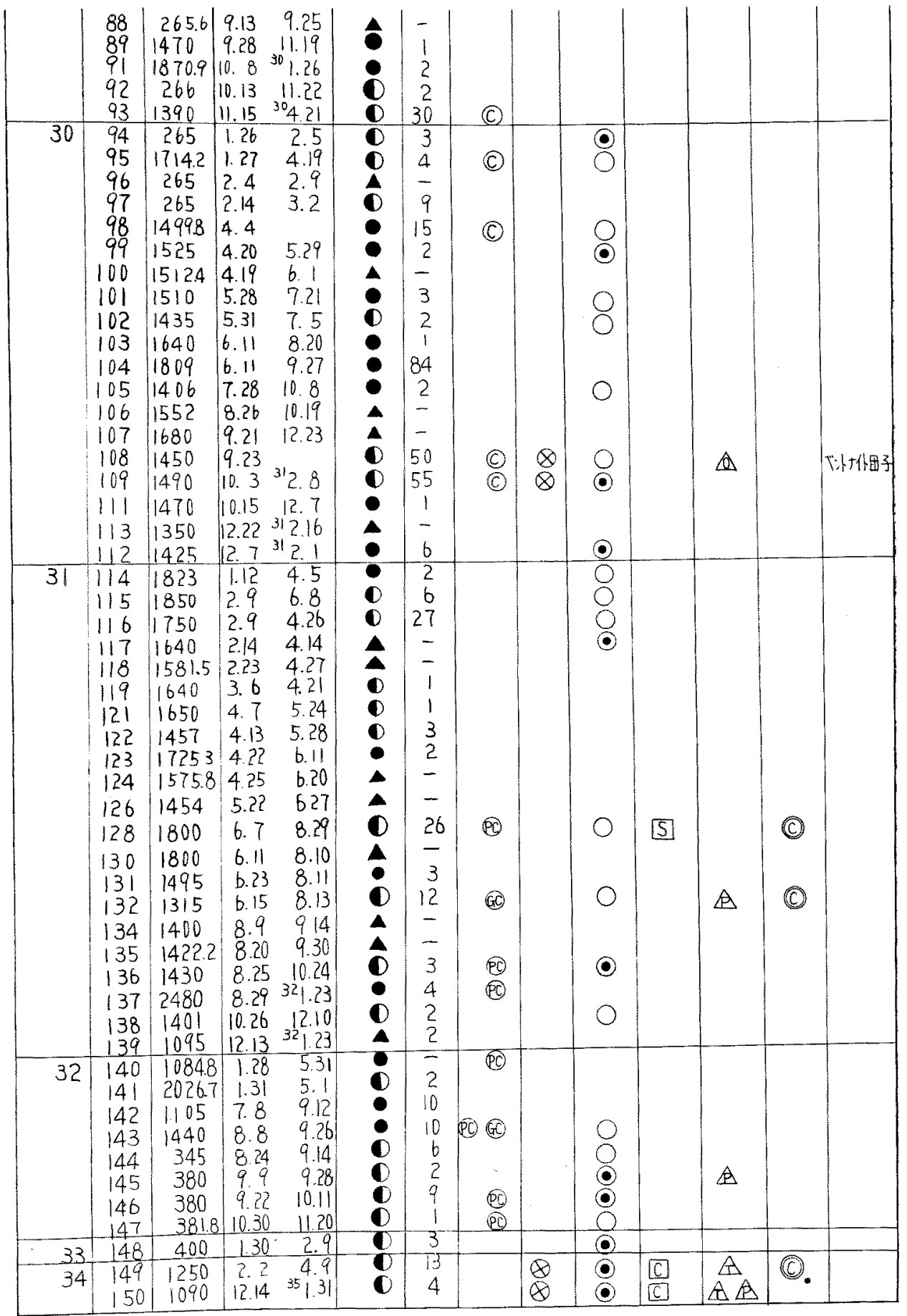

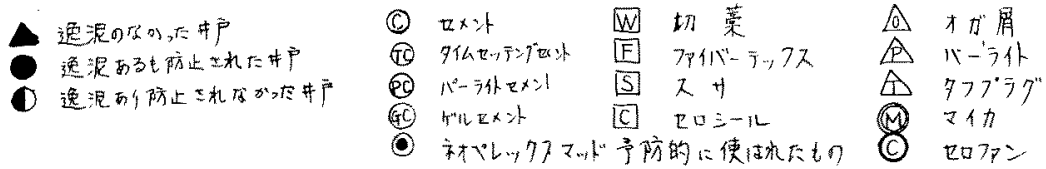


で異なつている。专れ故，逸泥対策に要した日数は淔接 比較される数字ではない。

\section{6. 附近の採油井に対する影響}

次にこれら逸泥の採油井に与えた影響について考えて みる。先に述べたように, 逸泥の著しい深度は八橋四層 から几層へ加けてであるが，どちらかといえば四層の方

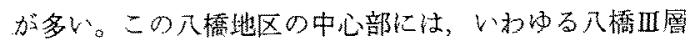
八橋ブロックがあり，水攻法が行われている。採油井の 多くは四層とIV層の同時仕上げであり，而層に対しての

\begin{tabular}{|c|c|c|}
\hline 胿 & 非各 & 樑 \\
\hline & 8 & 310.00 \\
\hline & 24 & 305.20 \\
\hline & 54 & 298.50 \\
\hline & 62 & 310.00 \\
\hline & 64 & 347.60 \\
\hline & 72 & 305.00 \\
\hline & 75 & 314.20 \\
\hline & 87 & 307.00 \\
\hline & 101 & 305.00 \\
\hline
\end{tabular}

み水压入が行われている。それで R. 149 および R. 150 号井の逸泥当時，その坑井付近の水圧入井および計䁷の 行われているその深度の採油井について調べてみた。る して対象井の籍囲は，一忘，R. 149，R. 150 の中間老中 心とし, 半径 $150 \mathrm{~m}$ 以内の坑井に限定した。第7図に それら坑井の位置を，また第2表にはその媣度を示す。

\section{第 7 図}

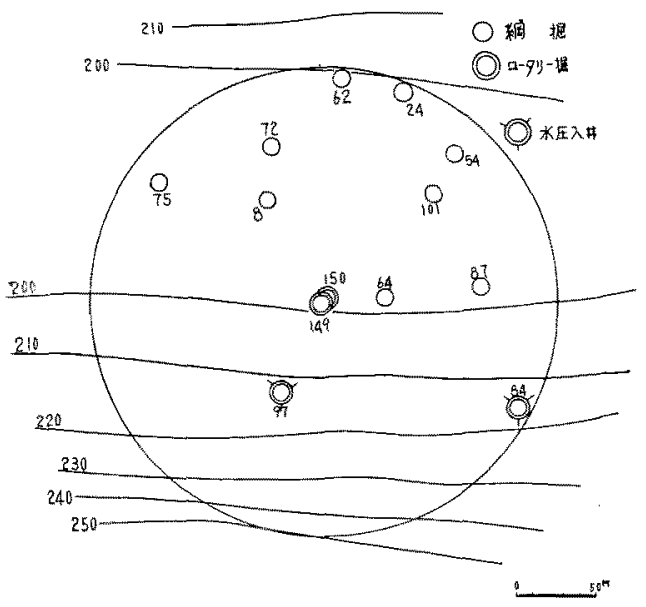

\section{R. 149 号井逸泥当状況}

最も近い水圧入井 R. 97 号井に抢いても压入量沾よび
圧力には変化がなかつた。また採油井の5ち，C. 64 号 井注没揚量に変化があり，C. $8 ，$ C. $72 ，$ C. 87 ，拉よび C. 101 号井等は，逸泥の影響を避汸るためポンプの運転 休止されている。これらの各犺井の汲揚量の変化を示 したものが第 8 图-1 である。この图に上ればは

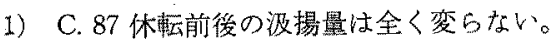

2）C. 64 は休転仙しなかつたが 12 日以㣪没揚量は $3: 5 \mathrm{kl}$ 程度增している。その内訳は第8図-2 に示寸が,

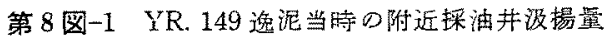

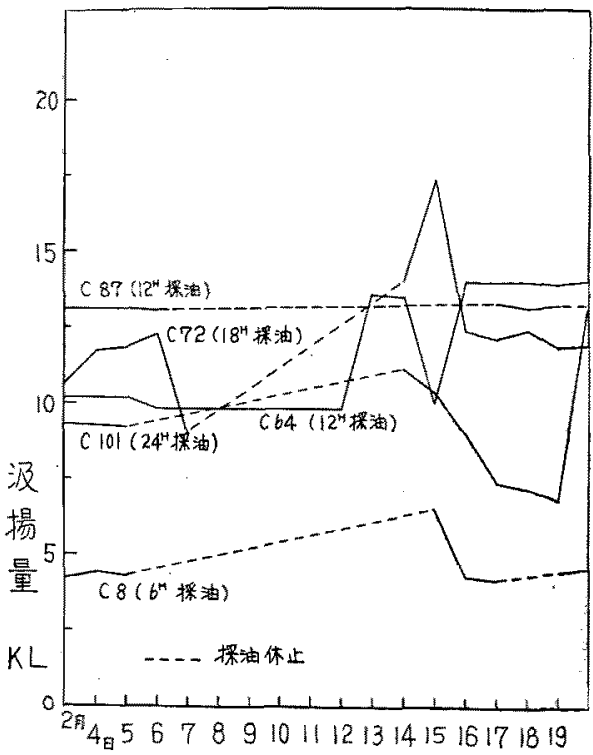

第 8 図-2 YR. 149 䢟泥当時 C. 64 の汲揚量

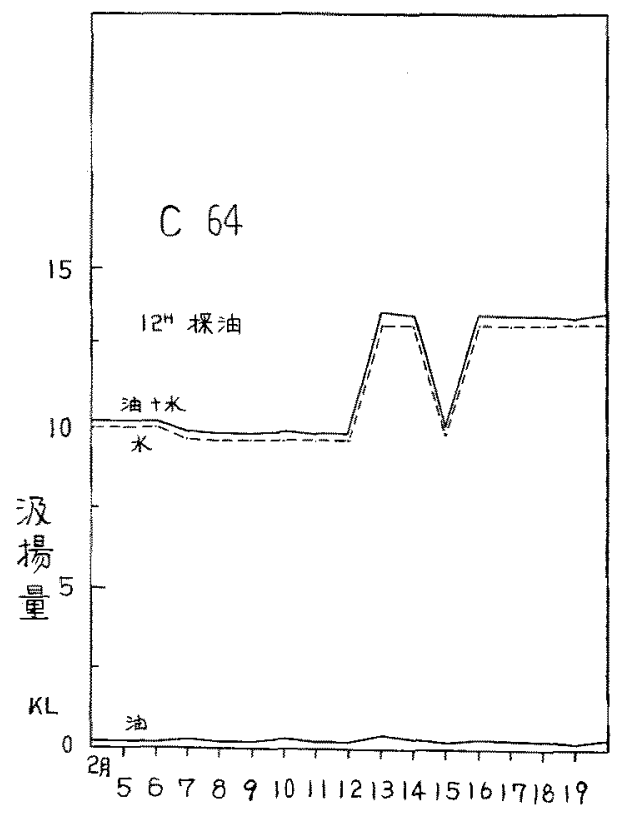


油量は同しであり，水量が增していることがわかる。こ の井戸上比較的近い距離にあるC. 87 が7日上り休転し ているけれども，17，18，19の3 日間は両坑井上もポン プされているにもからわらず，その間の汲揚量は変つて いない。したがつて C. 64 の扱揚量の增加は C. 8 休枟 に上るものでないと考えられる。

3）C.8は6日より14日安で休転したが，15日運転

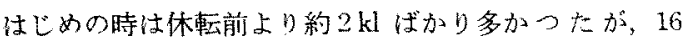
日加らは大体休転前上同量になっている。

4） C. 101 は休転後一時增したものが減つて休転前以 下となったが，20日より急に上昇して，25日 $21.7 \mathrm{kl}$. 26 日 $21.4 \mathrm{kl}$ となっており, その後次第化減少し，3月 21 日には $10.8 \mathrm{kl}$ になつている。

\section{R. 150 号井逸泥当時の状況}

この時にも圧入井に红何等変化がなかつた。东た逸泥 に際してポンプ運転を休止された採油井は，C. 8，C. 54, C. $62 ，$ C. $64 ，$ C. $72 ，$ C. 87 および C. 101 のて坑井であ つた。れら各坑井の汲揚量の変化は第 9 図儿示す。こ 第 9 図 YR. 150 遀泥当時の附近採油井没掦量

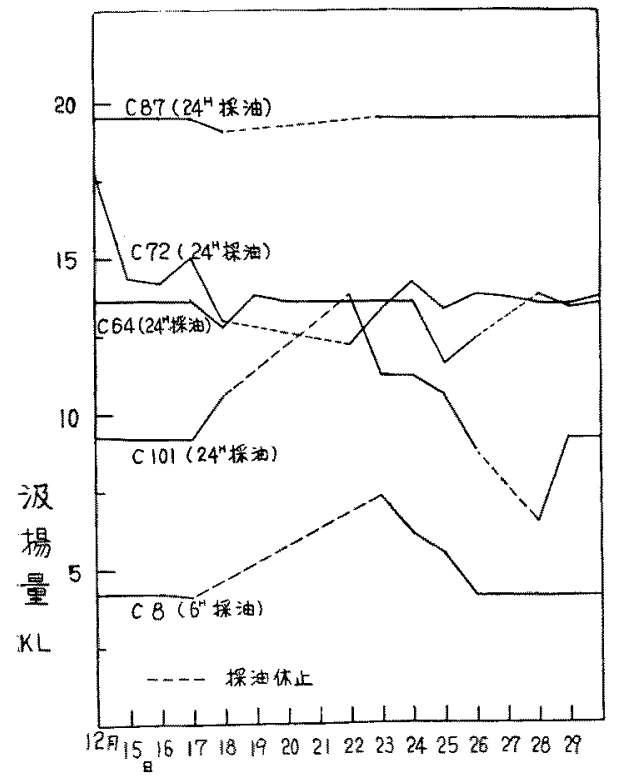

の図によれば，

1）C. 8 は休転捘 $3.3 \mathrm{kl}$ 增したが，26日に经休䎐前 と同量沈っている。

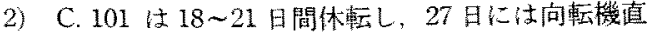
しのた休謓しているが，29日に慥泥に上る休転前 と同量になっているが、その間の㚆動は比転的大きい。

3) C. 64 は 18 日纪16時閒 40 分, 19 日红16 時間休 転しているが，注とんど変りがない。なお $18 ， 19$ 日の 汲揚量は 24 時間採油に換算してプロットしてある。

4） C. 72 号井は休転前上り変調があつたので，休転 による影響はわからない。

上にの心゙た没揚量恃すべて油上水の合計量であり、こ >では単に逸泥が没揚量にどの上うに影響するかについ て調ぐたのであって，圭の内訳については詳しく子れて ない。しかしこの結果からみると，恐らく逻泥に際し， 直ちに付近採油井の運転休止が行われたため上思われる が，逸泥に上る影響沙少ない。149号井逸泥当時のC.64

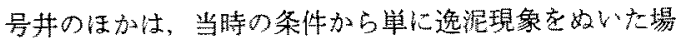
合で、これらの井戸を同時に休転させた時にも，これと 同じらな汲揚量の変動を示したか子しれない。

\section{7. 逸泥層の性状}

前にも述べたように，八橋地区の逸泥層汶非常に粗い 高渗透率の地層であることは容易比推定されるところで ある。YR.150 号井では，207.5 m で最初の逸泥が発生 したのであるが，75/8 八橋型ミーリンダコーア一器を 下げ，208.00 209.87 $\mathrm{m}$ の間を掘谁して，0.5 1.0 cm の小砂利が約 $1 l$ 採収され, さらに同器で 209.87 $210.90 \mathrm{~m}$ の間掘谁して，0.5 3.0 cm のかなり大き な砂利が約 $2 l$ 採収さ机た。したがつて自然の状態で は，これらの砂利に砂の混つた砂磂層に対し晩泥が起る ものであり，逸泥量の大きいことも当然であることがわ かった。恐らく流体の産出に伴なう油層圧の低下娄影響 していることであるう。しかして YR.150 付近が最も粗

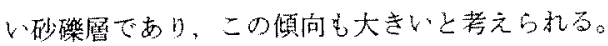

